\title{
Bone Morphogenic Protein 2-Loaded Porous Silicon Carriers for Osteoinductive Implants
}

\author{
Michal Rosenberg ${ }^{1,+}$, Dekel Shilo ${ }^{2,3,+}$, Leonid Galperin ${ }^{1}$, Tal Capucha ${ }^{2}$, Karim Tarabieh ${ }^{2}$, \\ Adi Rachmiel ${ }^{2,3}$ and Ester Segal 1,4,*(D) \\ 1 Department of Biotechnology and Food Engineering, Technion-Israel Institute of Technology, \\ Haifa 3200003, Israel; michirosros@gmail.com (M.R.); leonidgal@campus.technion.ac.il (L.G.) \\ 2 Department of Oral and Maxillofacial Surgery, Rambam Health Care Campus, Haifa 3109601, Israel; \\ D_shilo@rambam.health.gov.il (D.S.); capuchatal@gmail.com (T.C.); karim.t@campus.technion.ac.il (K.T.); \\ a_rachmiel@rambam.health.gov.il (A.R.) \\ 3 Bruce Rappaport Faculty of Medicine, Technion-Israel Institute of Technology, Haifa 3109601, Israel \\ 4 Russell Berrie Nanotechnology Institute, Technion-Israel Institute of Technology, Haifa 3200003, Israel \\ * Correspondence: esegal@technion.ac.il; Tel.: +972-4-8295071 \\ + The authors contribute equally to this work.
}

Received: 27 September 2019; Accepted: 8 November 2019; Published: 12 November 2019

\begin{abstract}
Bone morphogenetic proteins (BMPs) are probably the most important growth factors in bone formation and healing. However, the utilization of BMPs in clinical applications is mainly limited due to the protein poor solubility at physiological $\mathrm{pH}$, rapid clearance and relatively short biological half-life. Herein, we develop degradable porous silicon (PSi)-based carriers for sustained delivery of BMP-2. Two different loading approaches are examined, physical adsorption and covalent conjugation, and their effect on the protein loading and release rate is thoroughly studied. The entrapment of the protein within the PSi nanostructures preserved its bioactivity for inducing osteogenic differentiation of rabbit bone marrow mesenchymal stems cells (BM-MSCs). BM-MSCs cultured with the BMP-2 loaded PSi carriers exhibit a relatively high alkaline phosphatase (ALP) activity. We also demonstrate that exposure of MSCs to empty PSi (no protein) carriers generates some extent of differentiation due to the ability of the carrier's degradation products to induce osteoblast differentiation. Finally, we demonstrate the integration of these promising BMP-2 carriers within a 3D-printed patient-specific implant, constructed of poly(caprolactone) (PCL), as a potential bone graft for critical size bone defects.
\end{abstract}

Keywords: bone morphogenic protein 2; porous silicon; bone marrow mesenchymal stem cells; differentiation; osteoinduction; implants

\section{Introduction}

Bone morphogenetic proteins (BMPs) are a well-studied family of osteoinductive growth factors which are responsible for bone formation during embryogenesis, bone remodeling, and bone regeneration [1-3]. BMP-2 and BMP-7 have been approved by the US Food and Drug Administration (FDA) for treatment of acute and open fractures of the tibial shaft and for oral maxillofacial surgeries [1-3]. For the latter, FDA-approved INFUSE ${ }^{\circledR}$ bone grafts, which consists of recombinant human BMP-2 placed on an absorbable collagen sponge, are clinically-used to induce new bone tissue at the site of implantation [2]. Yet, the wide-spread use of BMPs for medical and dental applications is still limited due to its poor solubility at physiological $\mathrm{pH}$ [2,4-6], rapid clearance and relatively short biological half-life [2,7]. In addition, BMP-2 was found to induce ectopic bone formation, haematomas in soft tissues, and bone resorption around implants, and thus it is important to localize the protein to the required compartment in order to minimize these complications [8-10]. Therefore, a substantial research 
effort is focused on developing delivery systems for BMP-2 that will allow for controlled spatiotemporal release which would lower the administered dose, localize the protein delivery strictly to the defect region, prolong its retention time at the site of action, and maintain its stability. The majority of BMP-2 delivery systems are based on synthetic or natural polymers [8,11]. For the latter (e.g., collagen), their biodegradation is difficult to control, resulting in undefined release kinetics of the entrapped protein [12]. As for synthetic polymers, their acidic degradation products may locally reduce the $\mathrm{pH}$ and induce inflammation at the implant site. In addition to this acidification, tendency to hydrophobicity which is typical for many polymers, such as poly(lactic-co-glycolic acid), may compromise the protein stability [13]. Other drawbacks encountered with the use of some synthetic polymers include retarded clearance rate, lack of biological function and chronic inflammation associated with high molecular weight polymers [14-16]. Metal scaffolds made of titanium are commonly used as support scaffolds for bone repair applications [17,18]. However, BMP molecules incorporated into titanium support scaffolds are either adsorbed to the surfaces or are superficially entrapped and therefore can be rapidly released in vivo [15].

Porous silicon (PSi) has been extensively studied in recent years for drug delivery applications [19-21] owing to its high surface area and porous volume, combined with its biocompatibility, as well as its ability to degrade into non-toxic products under physiological conditions [22,23]. In addition, PSi has been shown to exhibit beneficial features in the field of bone regeneration [24-29], including its ability to induce hydroxyapatite growth [30,31]. PSi has been shown to promote osteoblast adherence and initiate maturation process [32]. Furthermore, its degradation product, orthosilicic acid, has been shown to induce osteodifferntiation of mesenchymal stem cells (MSCs) into osteoblasts in vitro [33].

Many studies have demonstrated the potential of PSi-based delivery systems for protein therapeutics [34-39]. Loading of proteins into PSi carriers can be carried out at low temperatures without the use of strong organic solvents, which is advantageous when dealing with these sensitive macromolecules [23,40,41]. Moreover, proteins can be loaded via simple electrostatic adsorption which is optimal for persevering their delicate tertiary structure. The process of protein loading into PSi depends on the properties of the porous matrix (e.g., pore size and surface chemistry), as well as those of the protein (e.g., molecular size and structure, charge and hydrophilicity/hydrophobicity). Of importance are also properties of the loading solvent in terms of $\mathrm{pH}$, ionic strength and composition [36,42-45]. The surface chemistry of the PSi exerts a major effect on the loading efficacy and can be easily tuned in order to better control the interactions between the protein molecules and the porous scaffold. These interactions subsequently dictate the structure of the adsorbed protein molecules and their bioactivity $[36,37,46]$.

The present work aims to employ PSi nanostructures as carriers for BMP-2, allowing for the protein's sustained release while retaining its biological activity. Two different loading approaches are examined, physical adsorption and covalent conjugation, and their effect on the loading and release kinetics is thoroughly studied. The fabricated carriers exhibit sustained release of the growth factor over a period of 35 days. The biological activity of the released BMP-2 was studied by characterizing its ability to stimulate osteogenic differentiation of bone marrow mesenchymal stem cells (BM-MSC). The degree of differentiation was examined by measuring the alkaline phosphatase (ALP) activity of MSCs after two weeks of exposure to the BMP-2 loaded PSi carriers. BM-MSCs cultured with BMP-2 loaded PSi carriers (via both physical adsorption and covalent attachment) exhibit relatively high ALP activity. Remarkably, empty PSi (no BMP-2) carriers have also demonstrated some degree of osteogenic differentiation, exhibiting an ALP activity which was significantly higher than that of the control untreated MSCs. After proving the therapeutic efficacy of this delivery system in vitro, we provide a glimpse to our current work, which focuses on the integration of these promising BMP-2 carriers within a 3D-printed patient-specific implant, constructed of poly(caprolactone) (PCL), as a bone graft for critical size bone defects. The latter affect more than 1.5 million people in the U.S. each year [47]. The loss or dysfunction of skeletal tissue due to trauma, ablative surgery, aging or diseases, can result 
in significant morbidity, as well as reduced quality of life. Current treatment strategies usually involve the use of autogenous bone grafts such as fibula, iliac crest and rib grafts as non-vascularized or as vascularized grafts. These grafts suffer from severe limitations including substantial challenging surgery, limited success, resorption of bone, donor-site morbidity, severe infections and residual pain [48-50]. Thus, there is an urgent need for developing new reliable bone regeneration strategies.

\section{Materials and Methods}

\subsection{Fabrication, Chemical Modification and Chracterization of $\mathrm{PSiO}_{2}$ Carriers}

PSi was fabricated by anodization of heavily p-doped Si wafers $(0.95 \mathrm{~m} \Omega \times \mathrm{cm}$ resistivity, $<100>$-oriented, B-doped, purchased from Sil' tronix Corp., Archamps, France). First, the Si wafers were thermally oxidized at $400{ }^{\circ} \mathrm{C}$ for $2 \mathrm{~h}$ in ambient air in a tube furnace (Thermo Scientific, Lindberg/Blue $\mathrm{M}^{\mathrm{TM}} 1200{ }^{\circ} \mathrm{C}$ Split-Hinge, Waltham, MA, USA), followed by incubation in a solution of aqueous hydrofluoric acid (HF) (48\%, Merck, Darmstadt, Germany), double-distilled water (ddH $\left.{ }_{2} \mathrm{O}\right)$ and ethanol (99.9\%, Merck, Darmstadt, Germany) (1:1:3 v/v) for $5 \mathrm{~min}$. Subsequently, the samples were anodized in a two-step process (the anodization setup details were previously reported [51]). The first stage included anodization at a constant current density of $250 \mathrm{~mA} \mathrm{~cm}{ }^{\mathrm{TM} 2}$ for $30 \mathrm{~s}$ in a solution of aqueous $\mathrm{HF}$ and ethanol at a ratio of 3:1 (v/v). The resulting PSi layer was dissolved in an aqueous $\mathrm{NaOH}$ solution (0.1 M, Sigma-Aldrich Chemicals, Rehovot, Israel). The second stage included anodization at $250 \mathrm{~mA} \mathrm{~cm}^{\mathrm{TM} 2}$ for $20 \mathrm{~s}$. After each anodization step, the silicon surface was thoroughly washed with ethanol and dried under a nitrogen stream. Following anodization, the resulting PSi film was thermally oxidized at $800^{\circ} \mathrm{C}$ for $1 \mathrm{~h}$ in ambient air, producing a porous $\mathrm{SiO}_{2}\left(\mathrm{PSiO}_{2}\right)$ scaffold. Next, a dicing saw (DAD3500; Disco, Tokyo, Japan) was used to cut the samples into $7 \mathrm{~mm} \times 3 \mathrm{~mm}$ rectangles. Before dicing, the samples were spin coated with AZ4533 photoresist (MetalChem, Lod, Israel) at $4000 \mathrm{rpm}$ for $1 \mathrm{~min}$, followed by baking at $90{ }^{\circ} \mathrm{C}$ for $2 \mathrm{~min}$. The diced samples were then soaked in acetone (Gadot, Haifa, Israel) for $3 \mathrm{~h}$ to remove the photoresist coating, thoroughly washed with ethanol and dried under a nitrogen stream. The physical properties of the neat $\mathrm{PSiO}_{2}$ samples (i.e., pore size and porous layer thickness) were studied by a Carl Zeiss Ultra Plus high-resolution scanning electron microscope (HR-SEM) at an accelerating voltage of $1 \mathrm{kV}$. The porosity of the $\mathrm{PSiO}_{2}$ was measured by gravimetry and spectroscopic liquid infiltration method (SLIM), as previously reported [51].

The chemically-modified $\mathrm{PSiO}_{2}$ carriers were prepared as follows: First, $\mathrm{PSiO}_{2}$ samples were amino-silanized by incubation in a solution of $1 \% v / v$ (3-Aminopropyl)triethoxysilane (APTES) in $\mathrm{ddH}_{2} \mathrm{O}$ and $1 \% v / v \mathrm{~N}-\mathrm{N}$-Diisopropylethylamine (DIEA) for $30 \mathrm{~min}$, followed by baking at $100{ }^{\circ} \mathrm{C}$ for $15 \mathrm{~min}$. Second, the amine-modified $\mathrm{PSiO}_{2}$ was incubated in a solution of succinic anhydride $\left(10 \mathrm{mg} \mathrm{mL}^{-1}\right)$ in acetonitrile and $2 \% v / v$ DIEA for $3 \mathrm{~h}$. After which, the surface was thoroughly rinsed for several times with acetonitrile and $\mathrm{ddH}_{2} \mathrm{O}$. Next, the samples were reacted with (ethyl-3-(3-(dimethylamino)propyl)carbodiimide) (EDC) (10 $\mathrm{mg} \mathrm{mL}^{-1}$ ) and (N-hydroxysulfosuccinimide sodium salt) (NHS) $\left(5 \mathrm{mg} \mathrm{mL}^{-1}\right)$ in phosphate buffer saline (PBS) at $\mathrm{pH}$ 7.2. Finally, the resulting modified $\mathrm{PSiO}_{2}$ carriers were rinsed with $\mathrm{PBS}(\mathrm{pH} 7.2)$ and dried under a nitrogen gas. Note that all reagents used for $\mathrm{PSiO}_{2}$ modification were obtained from Sigma-Aldrich Chemicals, Rehovot, Israel. Surface modification was verified using attenuated total reflectance Fourier transform infrared (ATR-FTIR) spectroscopy. Spectra were recorded using a Thermo 6700 FTIR instrument equipped with a Smart iTR diamond ATR device.

\subsection{BMP-2 Loading and Release from $\mathrm{PSiO}_{2}$ Carriers}

Bone morphogenetic protein-2 (BMP-2, Peprotech, Rehovot, Israel) was loaded into the $\mathrm{PSiO}_{2}$ carriers by physical adsorption and covalent attachment. In the physical adsorption approach, the protein loading was performed using the impregnation method [35,52]. The loading solution was prepared by dissolving $10 \mu \mathrm{g}$ of BMP-2 in a 1:1 $(v / v)$ solution of $\mathrm{PBS}$ and $\mathrm{ddH}_{2} \mathrm{O}$ to a final protein concentration of $20 \mu \mathrm{g} \mathrm{mL}-1.20 \mu \mathrm{L}$ of the latter solution were introduced onto the $\mathrm{PSiO}_{2}$ carrier (size 
of $7 \mathrm{~mm} \times 3 \mathrm{~mm}$ ) and allowed to infiltrate into the nanostructure for $2 \mathrm{~h}$; after which, the solution was collected (for subsequent quantification of BMP-2 content). For covalent conjugation of the protein, the BMP-2 loading solution was introduced onto the amine-reactive NHS-activated $\mathrm{PSiO}_{2}$ carriers and allowed to infiltrate and react with the activated NHS ester groups for $2 \mathrm{~h}$. Quantification of BMP-2 loading within the $\mathrm{PSiO}_{2}$ carriers was determined using BMP-2 ELISA kit (Peprotech, Rehovot, Israel) according to the manufacturer's protocol. BMP-2 loading within $\mathrm{PSiO}_{2}$ carriers was determined by subtracting the measured protein content within the collected post-loading solution from that of the initial loading solution. BMP-2 loading efficacy was calculated by the following equation:

$$
B M P 2 \text { loading ef ficacy }[\%]=\frac{\text { Weight of } B M P 2 \text { in } \mathrm{PSiO}_{2} \text { carrier }}{\text { Weight of } B M P 2 \text { in loading solution }} \times 100
$$

In vitro BMP-2 release studies were performed by incubating the $\mathrm{BMP}-2$-loaded $\mathrm{PSiO}_{2}$ carriers in $2 \mathrm{~mL}$ of PBS containing $1 \%$ bovine serum albumin fraction $\mathrm{v}$ (BSA) (MP Biomedicals, Irvine, CA, USA) and $0.02 \%$ sodium azide (Sigma-Aldrich Chemicals, Rehovot, Israel) at $37^{\circ} \mathrm{C}$. Every two days, aliquots were sampled and replaced with fresh PBS. The aliquots were then frozen in liquid nitrogen and stored at $-20{ }^{\circ} \mathrm{C}$ until further analysis using the BMP-2 ELISA kit.

\subsection{Isolation and Culture of Mesenchymal Stem Cells (MSCs) from Rabbit Bone Marrow (BM)}

The femur was isolated from a New Zealand rabbit, cleaned from soft tissues in Roselle Park Medical Institute (RPMI) medium (Biological Industries, Beit HaEmek, Israel), and sterilized by immersion in $70 \%$ ethanol for $1 \mathrm{~min}$. Subsequently, the femur was rinsed with sterile PBS and the bone ends were separated using sterile scissors. Next, bone marrow (BM) cells were eluted from the bone by flushing them with a sterile syringe filled with RPMI medium. The cell suspension was centrifuged at $1400 \mathrm{rpm}$ for $7 \mathrm{~min}$ and the supernatant was discarded. The cell pellet was resuspended in $21 \mathrm{~mL}$ of RPMI medium, followed by a subsequent centrifugation at $1400 \mathrm{rpm}$ for $7 \mathrm{~min}$. The supernatant was then discarded and the cell pellet was resuspended in $10 \mathrm{~mL}$ of RPMI medium supplemented with $10 \%$ fetal bovine serum (FBS), $1 \% \mathrm{~L}$-glutamine, $1 \%$ penicillin $\left(100 \mathrm{U} \mathrm{mL}^{-1}\right)$ streptomycin $\left(100 \mu \mathrm{g} \mathrm{mL}^{-1}\right)$ solution, $50 \mu \mathrm{g} \mathrm{mL}^{-1}$ gentamicin (all reagent were supplied by Biological Industries, Beit HaEmek, Israel) and $0.01 \% \beta$-mercaptoethanol (Sigma-Aldrich Chemicals, Rehovot, Israel). Next, the cell suspension was filtered through a 70- $\mu \mathrm{m}$ filter mesh (Corning, Corning, NY, USA) and counted by an automated cell counter (Countess II, Life Technologies, Waltham, MA, USA). The cells were then seeded into a T-75 culture flasks in a density of 6000 cells cm$^{-2}$, cultured for 2 weeks and maintained in a humidified incubator at $37^{\circ} \mathrm{C}$ containing $5 \% \mathrm{CO}_{2}$. The medium was replaced every 3 days.

\subsection{Cell Viability Assay}

Alamar Blue ${ }^{\mathrm{TM}}$ assay (Thermo Fisher Scientific, Waltham, MA, USA) was used to study the cytotoxicity of the $\mathrm{PSiO}_{2}$ carriers on BM MSCs. Briefly, $5 \times 10^{5}$ cells in $0.5 \mathrm{~mL}$ of RPMI medium were seeded in each well (24-well plates) and allowed to attach for $12 \mathrm{~h}$, followed by several rinsing with $0.5 \mathrm{~mL}$ of PBS. Then, empty neat $\mathrm{PSiO}_{2}$ and amine-reactive NHS-activated $\mathrm{PSiO}_{2}$ carriers (termed in this work as empty chemically-modified $\mathrm{PSiO}_{2}$ carriers), $\mathrm{BMP}$-2-loaded $\mathrm{PSiO}_{2}$ (via both physical adsorption and covalent conjugation) or a solution of free BMP-2 (50 $\left.\mathrm{ng} \mathrm{mL}^{-1}\right)$ with $0.5 \mathrm{~mL}$ of fresh growth medium. After 1, 3 and 6 days, the wells were washed twice with $0.5 \mathrm{~mL}$ of PBS and cells were incubated in $10 \%(v / v)$ Alamar blue solution for $4 \mathrm{~h}$ at $37{ }^{\circ} \mathrm{C}$ with $5 \% \mathrm{CO}_{2}$ and protected from light. Aliquots of $150 \mu \mathrm{L}$ were sampled from each well and the fluorescence intensity was quantified using a microplate reader (Varioskan Flash, Thermo Scientific, Waltham, MA, USA), $\lambda_{\mathrm{ex}}=535 \mathrm{~nm}$ and $\lambda_{\text {em }}=590 \mathrm{~nm}$. Cell viability is expressed as the fluorescence intensity of experimental wells normalized to respective values of control wells (cells only). 


\subsection{In Vitro BMP-2 Bioactivity Assay}

In vitro BMP-2 bioactivity assay was performed as follows: Second passage MSCs $\left(5 \times 10^{5}\right.$ cells) were seeded in $0.5 \mathrm{~mL}$ of RPMI medium in each well (24-well plates) and allowed to attach for $12 \mathrm{~h}$, followed by rinsing the wells twice with $0.5 \mathrm{~mL}$ of PBS. Subsequently, we introduced $0.5 \mathrm{~mL}$ of fresh growth medium containing the following different treatments: (i) empty neat $\mathrm{PSiO}_{2}$, (ii) empty chemically-modified $\mathrm{PSiO}_{2}$ carriers, (iii) $\mathrm{BMP}$-2-loaded $\mathrm{PSiO}_{2}$ (via physical adsorption), (iv) BMP-2-loaded $\mathrm{PSiO}_{2}$ (via covalent conjugation), (v) free BMP-2 solution (10 ng mL ${ }^{-1}$ ), (vi) free BMP-2 solution (50 $\mathrm{ng} \mathrm{mL}^{-1}$ ), (vii) free BMP-2 solution (100 $\mathrm{ng} \mathrm{mL}^{-1}$ ) and (viii) control untreated cells. One $\mathrm{PSiO}_{2}$ sample was introduced in each well, and all experiments were done in triplicates. After 7 days, the $\mathrm{PSiO}_{2}$ samples and the growth medium were replaced with fresh medium containing new $\mathrm{PSiO}_{2}$ samples (either empty or BMP-2 loaded) or free BMP-2 solutions, as described above, and the cells were maintained for additional 7 days in a humidified incubator at $37^{\circ} \mathrm{C}$ containing $5 \% \mathrm{CO}_{2}$. After 14 days, ALP activity was evaluated by performing ALP staining using the ab242286 ALP staining kit (Abcam, Tel Aviv, Israel) according to the manufacturer's protocol. Briefly, 14 days after induction of differentiation, the cells were washed with PBS containing 0.05\% Tween-20 (Sigma-Aldrich Chemicals, Rehovot, Israel). Next, cells were fixed by incubation with the kit's fixing solution for $2 \mathrm{~min}$, followed by two washes with PBS containing $0.05 \%$ Tween-20. The cells were then incubated with the kit's staining solution for $30 \mathrm{~min}$ and protected from light. Subsequently, the cells were washed twice with PBS and observed using an inverted light microscope (Nikon TE2000-S; Nikon Corporation, Japan and Leica DM18; Leica Microsystems, Wetzlar, Germany). Quantitative analysis of the positively-stained area in every image ( $n=5$ frames were taken for each well, all experiments were done in triplicates) was performed using the image processing program Fiji, a distribution of ImageJ (US National Institutes of Health, Bethesda, MD, USA).

\subsection{Integration of the $\mathrm{PSiO}_{2}$ Carriers into a 3D-Printed Scaffold for Critical Size Bone Defects}

A defect was created in a mandible of a New Zealand rabbit in accordance with the animal care and protection. Ethics approval was obtained from the RAMBAM Ethics Committee (approval number: IL0230218, 20 June 2018). The defect included the whole thickness of the bone and had a diameter of $10 \mathrm{~mm}$ to obtain a critical size defect. The implant was designed based on a computerized tomography (CT) scan of the defect in the animal using a Planmeca ProMax ${ }^{\circledR}$ 3D Max (Planmeca, Helsinki, Finland). The dicom files were converted into stereolithography (STL) 3D files using Philips IntelliSpace Portal (Philips, Amsterdam, Netherlands). The scaffold was designed using the Freeform Computer-aided design (CAD) program (Rock Hill, SC, USA) and included a slot for the $\mathrm{PSiO}_{2}$ carriers in the center of the scaffold, where two $\mathrm{PSiO}_{2}$ samples were fixed facing different directions. The scaffold was then printed from polycaprolactone (PCL) using an Ultimaker 2+ printer (Ultimaker, Utrecht, Netherlands).

\section{Results}

\subsection{Fabrication and Chemical Modifications of $\mathrm{PSiO}_{2}$ Carriers}

The PSi carriers were prepared by Si anodization at a constant current density of $250 \mathrm{~mA}$ $\mathrm{cm}^{-2}$ for $20 \mathrm{~s}$, followed by thermal oxidation and dicing, as schematically illustrated in Figure 1 . The anodization conditions were adjusted to efficiently accommodate the protein payload within the porous nanostructure, where BMP-2 has a molecular weight of $25.8 \mathrm{kDa}$ and a diameter of $\sim 4 \mathrm{~nm}[53,54]$. The structure of the resulting oxidized PSi $\left(\mathrm{PSiO}_{2}\right)$ films was characterized by HRSEM and their thickness was $\sim 3 \mu \mathrm{m}$ (Figure $2 \mathrm{~B}$ ) with a typical morphology of interconnecting cylindrical pores of approximately $40 \mathrm{~nm}$ in diameter (Figure 2A). The porosity of the films was determined by gravimetric studies [51], confirming their high porosity of $\sim 77 \%$. In this work, we studied two routes of protein loading; namely, physical adsorption and covalent attachment, as schematically illustrated in Figure 1. For the latter approach, the $\mathrm{PSiO}_{2}$ was first functionalized by amino-silanization (Figure 1Bi), which 
was followed by reaction with succinic anhydride. Subsequently, the BMP-2 protein was conjugated to the modified $\mathrm{PSiO}_{2}$ carriers via NHS and EDC coupling chemistry, see Figure 1B(iii,iv).
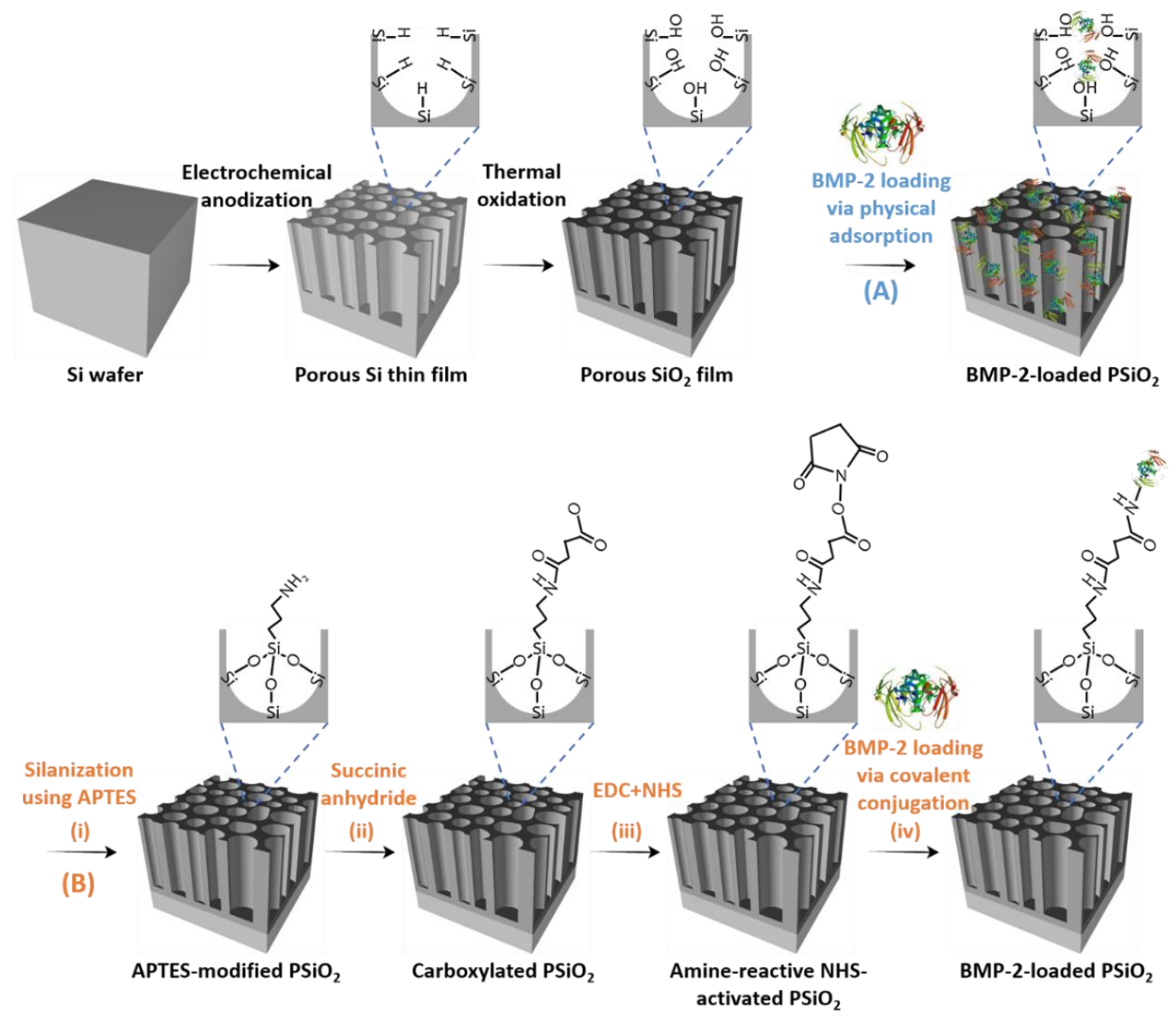

Figure 1. Schematic illustration of the fabrication of porous silicon (Psi) $\mathrm{O}_{2}$ carriers and subsequent bone morphogenetic protein (BMP)-2 loading via (A) Physical adsorption, or (B) Covalent attachment. A thin Si wafer is subjected to anodization at $250 \mathrm{~mA} \mathrm{~cm}^{-2}$ for $20 \mathrm{~s}$, followed by thermal oxidation at $800{ }^{\circ} \mathrm{C}$ for $1 \mathrm{~h}$ to produce a $\mathrm{PSiO}_{2}$ scaffold. For conjugation of the protein to the carrier, the $\mathrm{PSiO}_{2}$ is modified using the following steps: (i) Reaction with (3-aminopropyl)triethoxysilane (APTES) to form an amine-terminated $\mathrm{PSiO}_{2}$; (ii) Introduction of succinic anhydride to yield a carboxylated surface; (iii) Carboxyl groups are activated into a reactive $N$-hydroxysulfosuccinimide sodium salt (NHS) ester intermediates by ethyl-3-(3-(dimethylamino)propyl)carbodiimide (EDC) and NHS; (iv) Conjugation of BMP-2 is carried out through reaction of its primary amines with the amine-reactive NHS esters (note that the schematics are not drawn to scale).

The chemical functionalization on the $\mathrm{PSiO}_{2}$ surface was investigated using ATR-FTIR spectroscopy and the results are presented in Figure $2 \mathrm{C}$. The neat $\mathrm{PSiO}_{2}$ exhibits a characteristic $\mathrm{Si}-\mathrm{H}$ vibrating mode at $769 \mathrm{~cm}^{-1}$ and a peak at $1078 \mathrm{~cm}^{-1}$ that is attributed to the $\mathrm{Si}-\mathrm{O}-\mathrm{Si}$ stretching mode (data not shown). After the silanization step, a peak at $1626 \mathrm{~cm}^{-1}$ is observed, ascribed to the bending of the primary amines (Figure 2C(ii)) [51,55]. Following the modification with succinic anhydride, the spectrum shows two strong bands at 1551 and $1628 \mathrm{~cm}^{-1}$, see Figure $2 \mathrm{C}$ (iii), which are attributed to amide II and amide I bonds, respectively [51,55]. In addition, a peak at $1403 \mathrm{~cm}^{-1}$ is detected, assigned to the $\mathrm{C}-\mathrm{O}$ stretching and $\mathrm{O}-\mathrm{H}$ deformation vibrations of the carboxylic acid groups [56]. EDC/NHS coupling results in typical peaks at 1733 and $1778 \mathrm{~cm}^{-1}$, ascribed to the asymmetric and symmetric stretching bands of succinimidyl ester, respectively (Figure 2C(iv)) [51,55]. Following introduction of BMP-2, see Figure $2 \mathrm{C}(\mathrm{v})$, characteristic amide bands of proteins are observed at $1633 \mathrm{~cm}^{-1}$ (amide I) and $1553 \mathrm{~cm}^{-1}$ (amide II) [57]. 

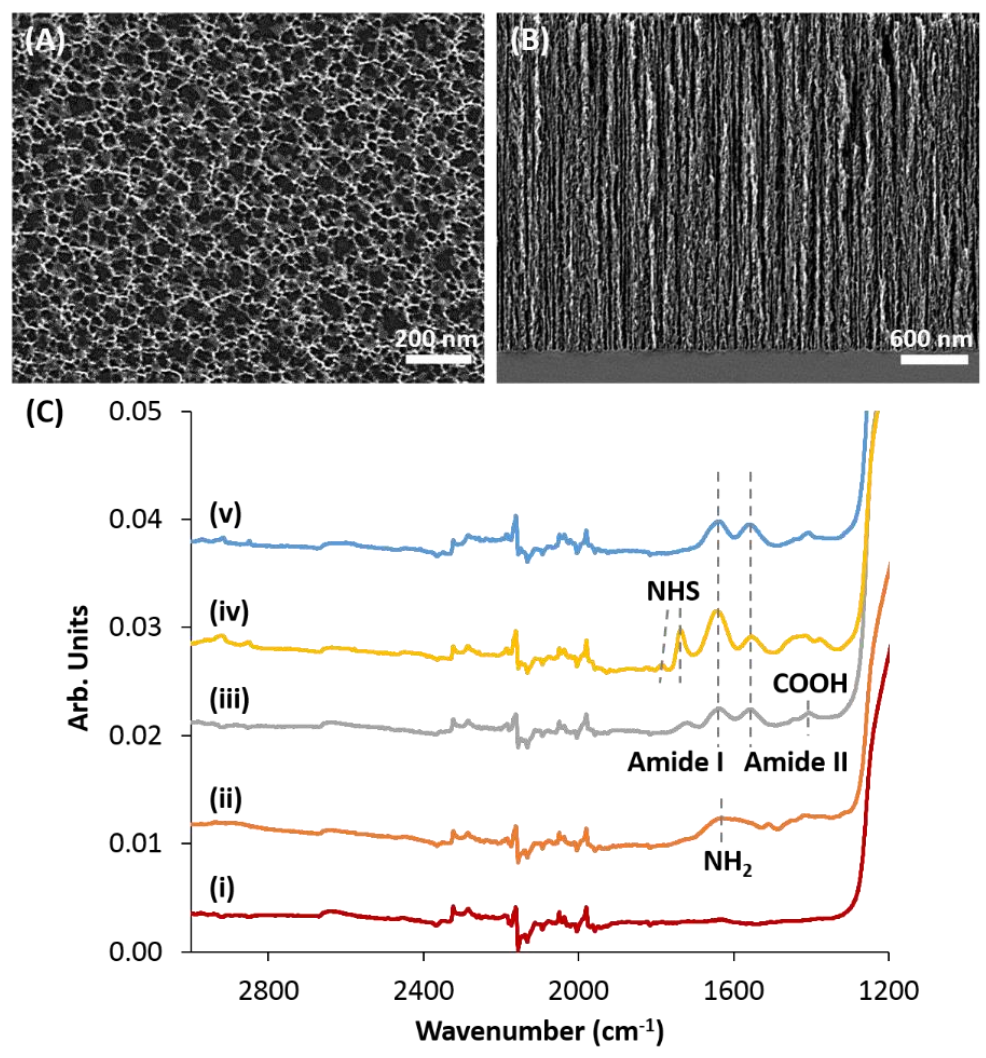

Figure 2. Characterization of the $\mathrm{PSiO}_{2}$ carriers by electron microscopy and ATR-FTIR spectroscopy. (A,B) Top-view and cross-section micrographs of a typical $\mathrm{PSiO}_{2}$ film etched at a current density of $250 \mathrm{~mA} \mathrm{~cm}^{-2}$ for $20 \mathrm{~s}$. (C) ATR-FTIR spectra of $\mathrm{PSiO}_{2}$ following the different chemical modification steps performed for covalent conjugation of BMP-2: (i) $\mathrm{Neat} \mathrm{PSiO}_{2}$; (ii) Amine-terminated surface after silanization with APTES; (iii) Carboxylated surface after modification with succinic anhydride; (iv) EDC/NHS activated surface; (v) BMP-2-conjugated $\mathrm{PSiO}_{2}$.

\subsection{BMP-2 Loading and Release from $\mathrm{PSiO}_{2}$ Carriers}

In this work, BMP-2 was loaded into the $\mathrm{PSiO}_{2}$ carriers by either physical adsorption or covalent attachment to the porous matrix. In the first method, the protein solution was allowed to infiltrate into the porous nanostructure and adsorption of the positively-charged BMP-2 molecules [3] to the negatively-charged $\mathrm{PSiO}_{2}$ surface is induced by favorable electrostatic interactions [36,38]. In the second approach, the BMP-2 protein was conjugated to the $\mathrm{PSiO}_{2}$ surface via EDC/NHS coupling chemistry, as illustrated in Figure 1B. Next, protein loading was quantified using a BMP-2 ELISA kit. Averaged protein content of $321 \pm 18 \mathrm{ng}$ and $167 \pm 15 \mathrm{ng}$ were achieved via physical adsorption and conjugation, respectively, corresponding to loading efficacy values of $82 \%$ and $43 \%(w / w)$. Release studies were performed in PBS (pH 7.4) at $37^{\circ} \mathrm{C}$ under sink conditions, where every two days aliquots were sampled and replaced with fresh PBS and the amount of BMP-2 released from the carriers was quantified using a BMP-2 ELISA kit. Figure 3A presents the BMP-2 release profile throughout a period of 35 days from the loaded $\mathrm{PSiO}_{2}$ carriers in terms of accumulative percentage (see Figure $\mathrm{S} 1$ for the corresponding mass of released BMP-2). Both $\mathrm{PSiO}_{2}$ carriers exhibit a sustained release of BMP-2, without a burst effect, over a period of $\sim 1$ month, regardless of the loading method. Figure $3 \mathrm{~B}$ presents the attained accumulative BMP-2 release values in comparison to the respective loading value for both loading methods. The release kinetics observed for both loading methods is similar throughout the studied period. Yet, when BMP- 2 was loaded via physical adsorption, only $46 \%$ of the protein was found to be released over a one-month period; whereas, in the case of the conjugated protein, $63 \%$ of the loaded BMP-2 was released, see Figure 3B. This behavior is clearly observed from day 4 of the study (Figure $3 \mathrm{~A}$ ) and is consistent throughout the consecutive weeks. 
(A)

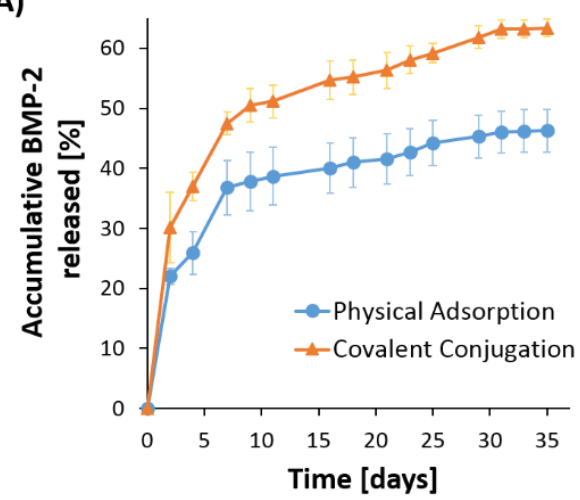

(B)

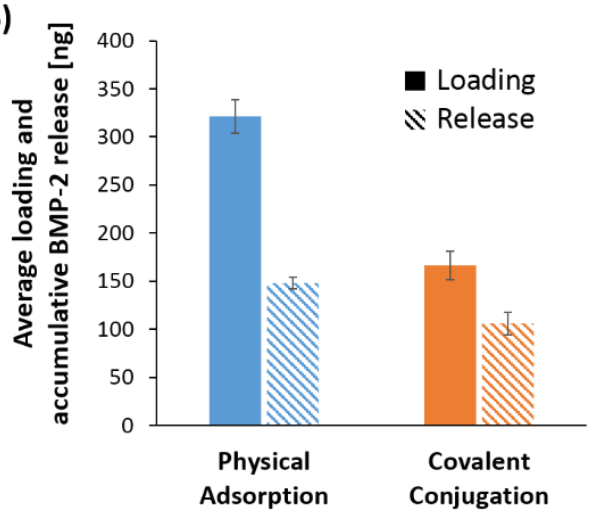

Figure 3. (A) BMP-2 release from $\mathrm{PSiO}_{2}$ carriers that were loaded by physical adsorption vs. covalent attachment of the protein. (B) Average BMP-2 loading and the corresponding accumulative release values for the two loading methods. Data represent mean $\pm \mathrm{SD}, n=3$.

\subsection{Cell Viability Studies for Proving the Biocompatibility of the $\mathrm{PSiO}_{2}$ Carriers.}

The in vitro cytotoxic effect of the $\mathrm{PSiO}_{2}$ carriers was studied by their incubation with rabbit bone marrow mesenchymal stem cells (BM-MSCs). The cells were incubated with empty and BMP-2-loaded $\mathrm{PSiO}_{2}$ carriers, or supplemented with free BMP-2 $\left(50 \mathrm{ng} \mathrm{mL}^{-1}\right)$. Viability was quantified on days 1 , 3 and 6 (post incubation) using the Alamar Blue ${ }^{\mathrm{TM}}$ assay and the results are summarized in Figure 4 and are normalized to cell viability values of the control untreated BM-MSCs. For all tested groups, the average relative cell viability was above $90 \%$ and no cytotoxic effect was observed. No significant differences were found between BM-MSCs cultured with neat and BMP-2-loaded $\mathrm{PSiO}_{2}$ carriers, as well as cells supplemented with free BMP-2 solution (as control). Thus, demonstrating the biocompatibility of the different carriers with the studied cells. It should be noted that previous studies suggested that resazurin-based viability assays (e.g., Presto Blue ${ }^{\mathrm{TM}}$ and Alamar Blue ${ }^{\mathrm{TM}}$ ) may be incompatible with PSi due to possible non-specific reduction of the dye by the $\mathrm{Si}$ and its degradation products [58]. Therefore, to assure the assay reliability, the $\mathrm{PSiO}_{2}$ carriers were removed and the cells were thoroughly washed with PBS prior to introduction of the Alamar Blue ${ }^{\mathrm{TM}}$ solution [59].

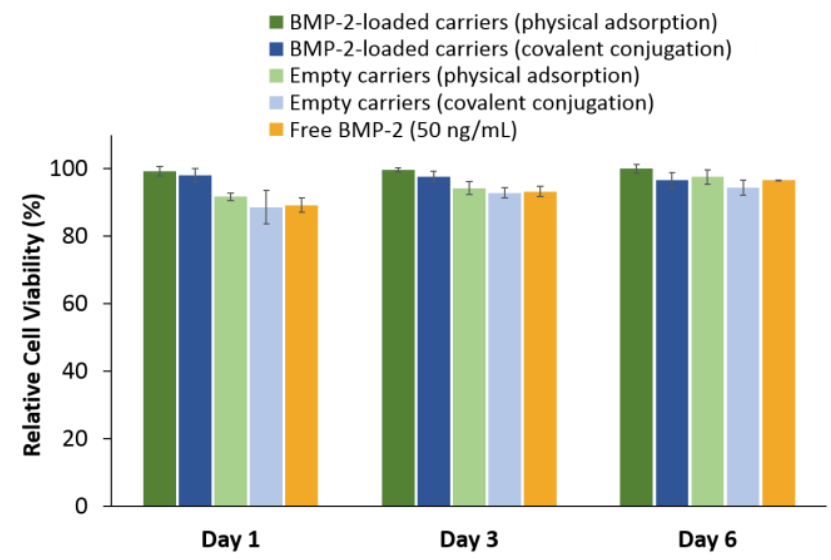

Figure 4. Cell viability of BM-MSCs grown with different $\mathrm{PSiO}_{2}$ carriers. The cells were cultured under one of the following conditions: (i) $\mathrm{BMP}$-2-loaded $\mathrm{PSiO}_{2}$ carriers which were loaded via physical adsorption or covalent conjugation; (ii) Empty $\mathrm{PSiO}_{2}$ carriers (both neat $\mathrm{PSiO}_{2}$ and chemically-modified $\mathrm{PSiO}_{2}$ carriers); (iii) Supplementation of free BMP-2 solution at a concentration of $50 \mathrm{ng} \mathrm{mL}-1$. Viability was tested on days 1, 3 and 6 . The results are normalized to control untreated BM-MSCs and are presented as relative viability. Cell viability was determined by the Alamar Blue ${ }^{\mathrm{TM}}$ assay $(n=3)$. 


\subsection{Evaluation of the Bioactivity of the Released BMP-2}

To evaluate if the BMP-2 released from the $\mathrm{PSiO}_{2}$ carriers has retained its bioactivity, we examined its ability to induce osteogenic differentiation of BM-MSCs into osteoblasts in vitro compared to that of free BMP-2 supplementation. Two weeks after the exposure of BM-MSCs to BMP-2-loaded $\mathrm{PSiO}_{2}$ carriers or to different concentrations of free BMP-2 $\left(10,50,100 \mathrm{ng} \mathrm{mL}^{-1}\right)$, the bioactivity of BMP-2, using osteogenic differentiation assessment, was evaluated by monitoring the enzyme alkaline phosphatase (ALP) activity, which is considered as one of the most commonly used markers of osteogenesis $[60,61]$. Fourteen days after induction of differentiation, cells were ALP-stained and observed under a light microscope. Figure 5A shows representative micrographs of the stained cells grown in the presence of BMP-2 loaded $\mathrm{PSiO}_{2}$ carriers in comparison to BM-MSCs cultured with empty carriers or supplemented with free BMP-2 solution (control untreated cells are also presented for reference). A strong red staining is observed for both cells grown with the BMP-2 loaded carriers (Figure 5A-i,iii) and supplemented with free BMP-2 (Figure 5A-v). A negligible number of stained BM-MSCs are observed in the control untreated cells. Notably, stained BM-MSCs are also observed when grown with empty $\mathrm{PSiO}_{2}$ carriers (Figure 5A-ii,iv), suggesting some degree of osteogenic differentiation. Representative micrographs of the stained cells at a higher magnification are presented in Figure S2.

Using image analysis software, the positively-stained areas were quantified and the results are summarized in Figure 5B. BM-MSCs cultured with BMP-2 loaded $\mathrm{PSiO}_{2}$ carriers (via both physical adsorption and covalent attachment) exhibit relatively high ALP activity, which is significantly higher than that achieved for treatment with free BMP-2 at concentration of $10 \mathrm{ng} \mathrm{mL}{ }^{-1}$ (Figure 5B). The extent of ALP activity obtained with the loaded $\mathrm{PSiO}_{2}$ carriers was equipotent to that obtained with free BMP-2 treatment at concentrations of $50-100 \mathrm{ng} \mathrm{mL}^{-1}$. Namely, the BMP-2 released from the $\mathrm{PSiO}_{2}$ carriers was found to exhibit at least the same biological activity compared to that of free BMP-2 (or higher, depending on the applied free BMP-2 concentration), indicating that it has retained its bioactivity upon entrapment and release from the $\mathrm{PSiO}_{2}$ carriers. Importantly, MSCs cultured with empty $\mathrm{PSiO}_{2}$ carriers also demonstrated some extent of ALP activity, which was significantly higher than that of the control untreated cells (Figure 5B). 
(A)
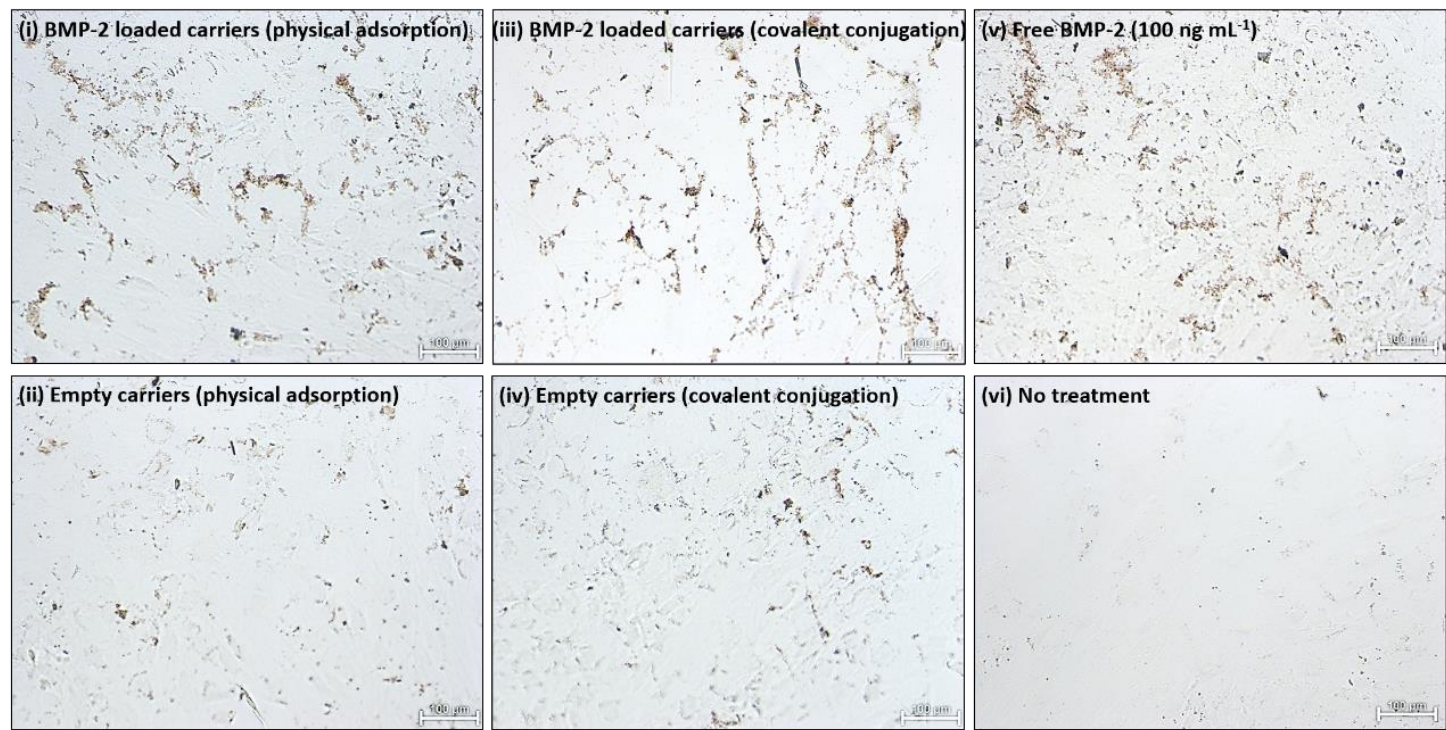

(iv) Empty carriers (covalent conjugation)

(vi) No treatment

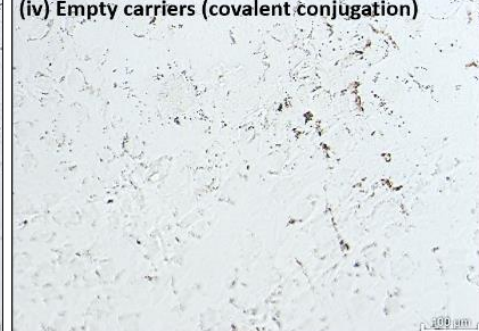

(B)

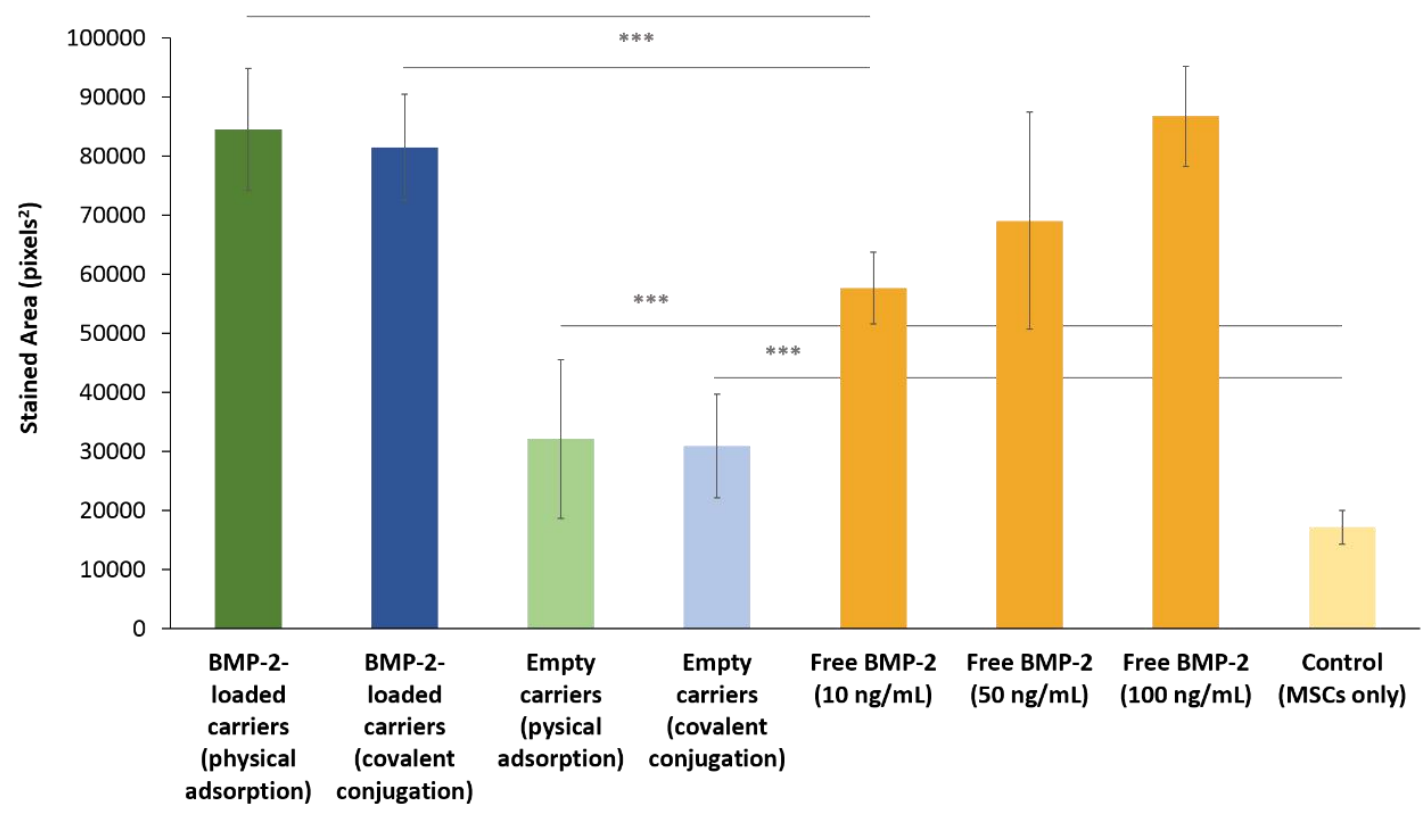

Figure 5. ALP staining of differentiated BM-MSCs after 14 days. (A) Representative light micrographs of cells exposed to (i) BMP-2-loaded $\mathrm{PSiO}_{2}$ carriers via physical adsorption, (ii) Empty $\mathrm{PSiO}_{2}$ carriers, (iii) BMP-2-loaded $\mathrm{PSiO}_{2}$ carriers via covalent conjugation, (iv) Empty chemically-modified $\mathrm{PSiO}_{2}$ carriers, (v) Free BMP-2 solution (100 ng mL ${ }^{-1}$ ) and (vi) no treatment (control, cells only). Scale bar $=100 \mu \mathrm{m}$. (B) Quantitative analysis of ALP activity, expressed as the average positively stained areas for each condition tested, ${ }^{* * *}$ indicates $p \leq 0.005$.

\subsection{Integration of the $\mathrm{PSiO}_{2}$ Carriers into a 3D-Printed Scaffold for Critical Size Bone Defects}

A nonhealing $10 \mathrm{~mm}$ full-thickness cylindrical defect was performed in a rabbit mandible. This defect removes both cortical plates and the intervening trabecular bone and tooth roots. Based on a CT scan of the mandible and using CAD software, a 3D model of the rabbit defected mandible was created. A customized graft, composed of a $10 \mathrm{~mm}$ round mesh, was designed, as shown in Figure 6A. The mesh is secured to the remaining bone using a solid bar (Figure 6A). Figure 6B presents the customized mesh graft, which is $10 \mathrm{~mm}$ in diameter and is comprised of square $500 \mu \mathrm{m}$ pores and $300 \mu \mathrm{m}$-thick walls. An insert for the $\mathrm{PSiO}_{2}$ carriers $(7 \mathrm{~mm} \times 3 \mathrm{~mm})$ is designed in the center of the mesh to accommodate two $\mathrm{PSiO}_{2}$ carriers facing opposite directions (Figure 6B). The customized graft 
was manufactured form poly(caprolactone) (PCL) by a 3D printer with a precision extruder deposition head (nozzle size $200 \mu \mathrm{m}$ ) system. Next, the $\mathrm{PSiO}_{2}$ carriers were incorporated within the PCL mesh and the integrated graft is shown in Figure 6C.
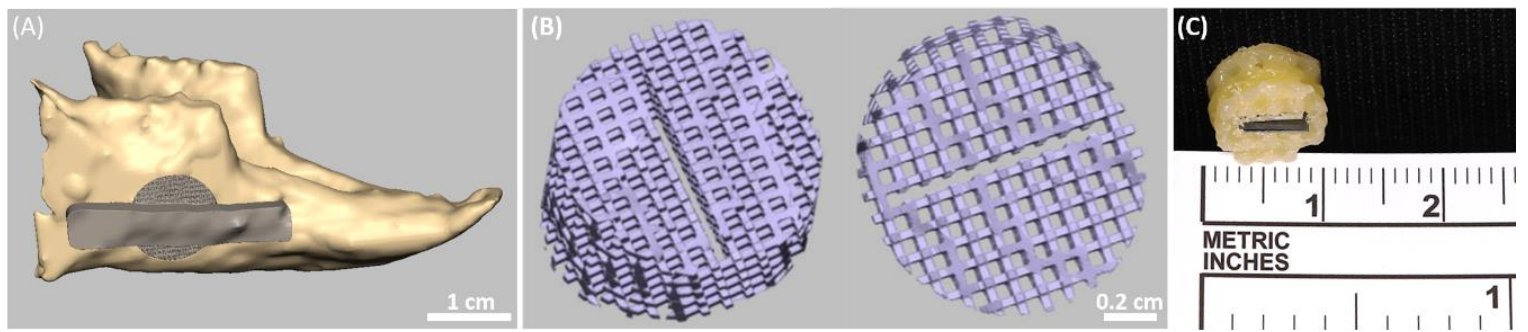

Figure 6. Design of the 3D printed scaffold for critical size bone defects. (A) 3D scanned rabbit mandible following bone resection and graft design using the freeform CAD program. (B) CAD design of the desired mesh (diameter of $10 \mathrm{~mm}$ ) with an insert in its center to accommodate the $\mathrm{PSiO}_{2}$ carriers. (C) The 3D-printed PCL mesh containing the $7 \mathrm{~mm} \times 3 \mathrm{~mm} \mathrm{PSiO}_{2}$ carrier.

\section{Discussion}

\subsection{BMP-2 Loading and Release from $\mathrm{PSiO}_{2}$ Carriers}

The two most common approaches for loading molecular payloads into PSi carriers are physical adsorption or covalent attachment of the drug molecules to the Si scaffold using a variety of different convenient surface chemistries available [62-64]. In the latter method, the drug cargo is only released when the covalent bonds are broken or when the supporting PSi is degraded [65]. In this work, the loading of BMP-2 to the $\mathrm{PSiO}_{2}$ carriers was studied by both physical adsorption and covalent attachment to the porous matrix using silanization and carbodiimide coupling chemistry, as shown in Figure 1. For physical adsorption, as the BMP is positively-charged in aqueous media [3], electrostatic interactions between the protein and the negatively-charged $\mathrm{PSiO}_{2}$ surface are highly favorable for efficient loading [34-39]. When comparing the loading of BMP-2 using these two methods, we find that physical adsorption of the protein results in a significantly higher loading capacity compared to the covalent conjugation method (Figure 3B). In fact, the amount of BMP-2 entrapped within the carriers that were loaded via physical adsorption was almost double than the values achieved by covalent attachment. This behavior is attributed to the fundamental differences between these two methods. In covalent attachment, the cargo load is controlled by the density of the grafted linkers and the subsequent conjugation reaction yield within the nanostructured pores, which is also affected by hindered diffusion of the protein macromolecules. Moreover, the payload conjugation requires surface functionalization of the porous scaffold which in turn results in a reduced available pore volume [66]. Thus, the loading capacity (for a given loading solution) in this loading method is inevitably lower than that achieved by non-covalent loading techniques, such as the physical adsorption method [67-69]. In addition, possible denaturation of the sensitive protein molecules during conjugation can also account for the lower measured (quantified by ELISA) amount of BMP-2 loaded for the covalent attachment. Specifically, it is suggested that the abundance of primary amines in the side chain of lysine residues and the N-terminus of BMP-2, serving as targets for the NHS/EDC reagents, can lead to increased heterogeneity and restricted conformational flexibility due to multipoint attachment on the modified $\mathrm{PSiO}_{2}$ surface, favoring protein denaturation [70]. Importantly, the amount of loaded BMP-2 for both loading methods investigated in the present study correlates to clinically-relevant dose for in vitro induction of osteogenic differentiation [71-73].

The BMP-2-loaded $\mathrm{PSiO}_{2}$ carriers exhibit a sustained release of BMP-2 over a period of 35 days (Figure 3A). The prolonged release span reported here is longer than that achieved in other BMP-2 delivery systems that are based on silica nanotube meshes [74], carbon nanoparticles [75], composite poly(L-lactic-co-glycolic acid) and mesoporous silica membranes [76], as well as 
poly(L-lysine)/hyaluronan films [77]. As already pointed out, one of the main challenges in the delivery of BMP-2 is its rapid clearance rate [2,7]. Thus, the capability of the $\mathrm{PSiO}_{2}$ carriers to sustain the release of the protein for several weeks, while localizing its administration to the injured site, is highly advantageous.

When comparing the release behavior from the loaded $\mathrm{PSiO}_{2}$ carriers, we found that carriers loaded via the covalent conjugation method exhibit higher percentage of released BMP-2, out of the total amount loaded, than that achieved via the physical adsorption method, see Figure 3B. This result may suggest that in the present case, the conjugation process actually stabilize the protein [78], while other effects such as the solubility of the protein conjugates (to Si moieties) cannot be excluded.

\subsection{Cell Viability and Bioactivity of the Released BMP-2}

The in vitro cytotoxicity of the $\mathrm{PSiO}_{2}$ carriers, BMP-2-loaded and empty, was studied by their incubation with BM-MSCs cultures. These multipotent cells are the progenitor cells for osteoblasts, adipocytes, and chondrocytes and are widely used in the field of bone regeneration to study osteogenic differentiation [79-81]. The results presented in Figure 4 show no cytotoxic effect for both empty and BMP-2-loaded $\mathrm{PSiO}_{2}$ carriers. The viability of the BM-MSCs was comparable to that of the untreated cells, as well as to that of cells supplemented with free BMP-2 solution. Thus, confirming that the $\mathrm{PSiO}_{2}$ carriers are biocompatible with rabbit MSCs, in agreement with previous studies with these cells $[29,82,83]$.

To confirm that the entrapment of BMP-2 within the $\mathrm{PSiO}_{2}$ carriers via either physical adsorption or covalent conjugation did not impede the bioactivity of the protein, we examined the ability of the released growth factor to induce osteogenic differentiation of rabbit BM-MSCs into osteoblasts compared to that of free BMP-2. It is well-established that when cultured in osteogenic media, MSCs tend to express markers which are characteristic of bone forming osteoblasts. BMPs are the most potent inducers of osteoblastic differentiation [84] and they are known to stimulate the primary signal for the differentiation of non-committed pluripotent cells into mineral-depositing osteoblasts [85]. Local administration of BMPs induces bone regeneration process. In vitro, osteogenic differentiation occurs throughout a period of 1 month. During the first two weeks, downregulation of DNA replication occurs and the cells begin to express osteoblast markers, mainly the enzyme ALP [86]. ALP plays an important role in the degradation of inorganic pyrophosphate, providing sufficient local concentration of phosphate or inorganic pyrophosphate required for mineralization. Therefore, ALP is commonly used as osteogenic differentiation marker, representing the degree of osteogenic differentiation $[60,61]$. Thus, we have exposed the BM-MSCs to the BMP-2 loaded $\mathrm{PSiO}_{2}$ carriers or to different free BMP-2 concentrations and ALP activity was measured 14 days later. We found that BMP-2 released from the $\mathrm{PSiO}_{2}$ carriers (regardless of the loading method) has retained its bioactivity and induced significant osteogenic differentiation, equivalent to that achieved by free BMP-2 solutions at concentrations of 50-100 ng mL ${ }^{-1}$, see Figure 5B. Remarkably, the empty $\mathrm{PSiO}_{2}$ carriers have also demonstrated some degree of differentiation, with an ALP activity which was significantly higher than the control untreated MSCs. We ascribe this behavior to the release of silicic acid moieties, during the erosion of the porous scaffold, into the culture media. Orthosilicic acid was already reported to stimulate osteoblast differentiation in vitro by upregulating microRNA-146a to antagonize NF-KB activation [33]. It has also been suggested that Si plays an important role in the expression of ALP [24]. In addition, Hing et al. [26]. have shown that incorporation of $\mathrm{Si}$ in porous hydroxyapatite implants is beneficial for early bone repair and new bone deposition. Thus, by enhancing osteogenic differentiation of MSCs, the combination of PSi and BMPs offers an interesting perspective for bone reparation and regeneration.

\subsection{Integration of the $\mathrm{PSiO}_{2}$ Carriers into a 3D-Printed Scaffold for Critical Size Bone Defects}

A critical size defect is an ideal model for testing bone regeneration platforms. Geometry of a $10 \mathrm{~mm}$ cylindrical defect was chosen for this study as it is easily accessible and reproducible [87]. A customized graft was designed to fit this critical size defect created in the rabbit mandible, comprised of square 
$500 \mu \mathrm{m}$ pores and $300 \mu \mathrm{m}$-thick walls (Figure $6 \mathrm{~A}$ ). One of the most important characteristics of the scaffold is a high interconnected porosity to enable vascularization for nutrient and gas diffusion, which permits waste disposal $[25,88,89]$. Smaller pore sizes $(<200 \mu \mathrm{m})$ have been shown to result in a limited bone formation due to insufficient accessible pore volume, limited oxygen diffusion, and vascular invasion. A pore size of $500 \mu \mathrm{m}$ is considered as an effective scaffold pore size which enables increased oxygen diffusion, pre-osteoblast cell infiltration, proliferation, and survival throughout the entire scaffold $[90,91]$. As the role of the $\mathrm{PSiO}_{2}$ is to provide a reservoir for the sustained delivery of the BMP-2 protein, we have localized the $\mathrm{PSiO}_{2}$ carriers in the center of the defect facing opposite directions (Figure 6C) to allow for optimal spatial distribution of the released protein in vivo. PCL was chosen as the printing material as it is a thermoplastic biocompatible material, with mechanical properties that resemble those of a trabecular bone, and thus would be sufficient to withstand the physiological forces of mastication. This polymer is characterized by a relatively slow degradation rate of 3-6 months [92-95] and thus can maintain physical integrity for primary stability in cases of large deficiencies.

In summary, utilizing PSi-based delivery systems for local administration of osteoinductive growth factors and their integration within biodegradable osteoinductive implants opens up great possibilities for efficient bone-regeneration therapies. Our current work is focused on studying the therapeutic efficacy of the integrated grafts in vivo.

Supplementary Materials: The following are available online at http://www.mdpi.com/1999-4923/11/11/602/s1, Figure S1: BMP-2 release from $\mathrm{PSiO}_{2}$ carriers that were loaded by physical adsorption vs. covalent attachment of the protein, expressed as the accumulative BMP-2 mass released over time. Figure S2: ALP staining of differentiated BM-MSCs after 14 days. Representative light micrographs of cells exposed to (i) BMP-2-loaded $\mathrm{PSiO}_{2}$ carriers via physical adsorption, (ii) $\mathrm{BMP}-2$-loaded $\mathrm{PSiO}_{2}$ carriers via covalent conjugation, (iii) Empty $\mathrm{PSiO}_{2}$ carriers, (iv) empty chemically-modified $\mathrm{PSiO}_{2}$ carriers, (v) Free BMP-2 solution (100 ng mL ${ }^{-1}$ ) and (vi) No treatment (control, cells only). Scale bar $=75 \mu \mathrm{m}$.

Author Contributions: Conceptualization, D.S. and E.S.; methodology, M.R., D.S., and A.R.; investigation and data analysis, M.R., L.G., D.S., T.C., and K.T., writing and reviewing, M.R., D.S. and E.S.; funding acquisition, D.S. and E.S.

Funding: This research was partially supported by the Lorry I. Lokey Interdisciplinary Center for Life Sciences and Engineering and the Russell Berrie Nanotechnology Institute.

Acknowledgments: M.R. is most grateful for the Russell Berrie Scholarships for Outstanding Graduate Students.

Conflicts of Interest: The authors declare no conflict of interest.

\section{References}

1. Bessa, P.C.; Casal, M.; Reis, R.L. Bone morphogenetic proteins in tissue engineering: The road from laboratory to clinic, part II (BMP delivery). J. Tissue Eng. Regen. Med. 2008, 2, 81-96. [CrossRef] [PubMed]

2. El Bialy, I.; Jiskoot, W.; Nejadnik, M.R. Formulation, delivery and stability of bone morphogenetic proteins for effective bone regeneration. Pharm. Res. 2017, 34, 1152-1170. [CrossRef] [PubMed]

3. Wozney, J.M. Bone morphogenetic proteins. Prog. Growth Factor Res. 1989, 1, 267-280. [CrossRef]

4. ImmunoTools GmbH. Recombinant Human Bone Morphogenetic Protein-2 (rh BMP-2). Available online: http://www.immunotools.de/html/cytokines.html (accessed on 27 October 2019).

5. Friess, W.; Uludag, H.; Foskett, S.; Biron, R. Bone regeneration with recombinant human bone morphogenetic protein-2 (rhBMP-2) using absorbable collagen sponges (ACS): Influence of processing on ACS characteristics and formulation. Pharm. Dev. Technol. 1999, 4, 387-396. [CrossRef] [PubMed]

6. Vallejo, L.F.; Rinas, U. Optimized procedure for renaturation of recombinant human bone morphogenetic protein-2 at high protein concentration. Biotechnol. Bioeng. 2004, 85, 601-609. [CrossRef] [PubMed]

7. Lo, K.W.-H.; Ulery, B.D.; Ashe, K.M.; Laurencin, C.T. Studies of bone morphogenetic protein-based surgical repair. Adv. Drug Deliv. Rev. 2012, 64, 1277-1291. [CrossRef] [PubMed]

8. Ben-David, D.; Srouji, S.; Shapira-Schweitzer, K.; Kossover, O.; Ivanir, E.; Kuhn, G.; Müller, R.; Seliktar, D.; Livne, E. Low dose BMP-2 treatment for bone repair using a PEGylated fibrinogen hydrogel matrix. Biomaterials 2013, 34, 2902-2910. [CrossRef] [PubMed] 
9. Gottfried, O.N.; Dailey, A.T. Mesenchymal stem cell and gene therapies for spinal fusion. Neurosurgery 2008, 63, 380-392. [CrossRef] [PubMed]

10. Villavicencio, A.T.; Burneikiene, S.; Nelson, E.L.; Bulsara, K.R.; Favors, M.; Thramann, J. Safety of transforaminal lumbar interbody fusion and intervertebral recombinant human bone morphogenetic protein-2. J. Neurosurg. Spine 2005, 3, 436-443. [CrossRef] [PubMed]

11. Kolambkar, Y.M.; Boerckel, J.D.; Dupont, K.M.; Bajin, M.; Huebsch, N.; Mooney, D.J.; Hutmacher, D.W.; Guldberg, R.E. Spatiotemporal delivery of bone morphogenetic protein enhances functional repair of segmental bone defects. Bone 2011, 49, 485-492. [CrossRef] [PubMed]

12. Tan, K.J.; Liao, S.; Chan, C.K. Controlled release of recombinant human bone morphogenetic protein-7 in nanoscaffolds. Nanomedicine 2007, 2, 385-390. [CrossRef] [PubMed]

13. Van de Weert, M.; Hennink, W.E.; Jiskoot, W. Protein instability in poly (lactic-co-glycolic acid) microparticles. Pharm. Res. 2000, 17, 1159-1167. [CrossRef] [PubMed]

14. Haidar, Z.S.; Hamdy, R.C.; Tabrizian, M. Delivery of recombinant bone morphogenetic proteins for bone regeneration and repair. Part B: Delivery systems for BMPs in orthopaedic and craniofacial tissue engineering. Biotechnol. Lett. 2009, 31, 1825-1835. [CrossRef] [PubMed]

15. Lee, S.-H.; Shin, H. Matrices and scaffolds for delivery of bioactive molecules in bone and cartilage tissue engineering. Adv. Drug Deliv. Rev. 2007, 59, 339-359. [CrossRef] [PubMed]

16. Seeherman, H.; Wozney, J.M. Delivery of bone morphogenetic proteins for orthopedic tissue regeneration. Cytokine Growth Factor Rev. 2005, 16, 329-345. [CrossRef] [PubMed]

17. Dabrowski, B.; Swieszkowski, W.; Godlinski, D.; Kurzydlowski, K.J. Highly porous titanium scaffolds for orthopaedic applications. J. Biomed. Mater. Res. Part B Appl. Biomater. 2010, 95, 53-61. [CrossRef] [PubMed]

18. Walboomers, X.F.; Jansen, J.A. Bone tissue induction, using a COLLOSS ${ }^{\circledR}$-filled titanium fibre mesh-scaffolding material. Biomaterials 2005, 26, 4779-4785. [CrossRef] [PubMed]

19. Gu, L.; Park, J.H.; Duong, K.H.; Ruoslahti, E.; Sailor, M.J. Magnetic luminescent porous silicon microparticles for localized delivery of molecular drug payloads. Small 2010, 6, 2546-2552. [CrossRef] [PubMed]

20. Santos, H.A.; Mäkilä, E.; Airaksinen, A.J.; Bimbo, L.M.; Hirvonen, J. Porous silicon nanoparticles for nanomedicine: Preparation and biomedical applications. Nanomedicine 2014, 9, 535-554. [CrossRef] [PubMed]

21. Tasciotti, E.; Liu, X.; Bhavane, R.; Plant, K.; Leonard, A.D.; Price, B.K.; Cheng, M.M.-C.; Decuzzi, P.; Tour, J.M.; Robertson, F. Mesoporous silicon particles as a multistage delivery system for imaging and therapeutic applications. Nat. Nanotechnol. 2008, 3, 151. [CrossRef] [PubMed]

22. Anglin, E.J.; Cheng, L.; Freeman, W.R.; Sailor, M.J. Porous silicon in drug delivery devices and materials. Adv. Drug Deliv. Rev. 2008, 60, 1266-1277. [CrossRef] [PubMed]

23. Salonen, J.; Kaukonen, A.M.; Hirvonen, J.; Lehto, V.-P. Mesoporous silicon in drug delivery applications. J. Pharm. Sci. 2008, 97, 632-653. [CrossRef] [PubMed]

24. Fan, D.; Akkaraju, G.R.; Couch, E.F.; Canham, L.T.; Coffer, J.L. The role of nanostructured mesoporous silicon in discriminating in vitro calcification for electrospun composite tissue engineering scaffolds. Nanoscale 2011, 3, 354-361. [CrossRef] [PubMed]

25. Gutiérrez-Prieto, S.J.; Perdomo-Lara, S.J.; Diaz-Peraza, J.M.; Sequeda-Castañeda, L.G. Analysis of in vitro osteoblast culture on scaffolds for future bone regeneration purposes in dentistry. Adv. Pharmacol. Sci. 2019, 2019, 5420752. [CrossRef] [PubMed]

26. Hing, K.A.; Revell, P.A.; Smith, N.; Buckland, T. Effect of silicon level on rate, quality and progression of bone healing within silicate-substituted porous hydroxyapatite scaffolds. Biomaterials 2006, 27, 5014-5026. [CrossRef] [PubMed]

27. Murphy, M.B.; Blashki, D.; Buchanan, R.M.; Fan, D.; De Rosa, E.; Shah, R.N.; Stupp, S.I.; Weiner, B.K.; Simmons, P.J.; Ferrari, M.; et al. Multi-Composite bioactive osteogenic sponges featuring mesenchymal stem cells, platelet-rich plasma, nanoporous silicon enclosures, and peptide amphiphiles for rapid bone regeneration. J. Funct. Biomater. 2011, 2, 39-66. [CrossRef] [PubMed]

28. Pastor, E.L.; Reguera-Nuñez, E.; Matveeva, E.; Garcia-Fuentes, M. Pore size is a critical parameter for obtaining sustained protein release from electrochemically synthesized mesoporous silicon microparticles. PeerJ 2015, 3, e1277. [CrossRef] [PubMed] 
29. Whitehead, M.A.; Fan, D.; Mukherjee, P.; Akkaraju, G.R.; Canham, L.T.; Coffer, J.L. High-Porosity poly ( $\varepsilon$-caprolactone)/mesoporous silicon scaffolds: Calcium phosphate deposition and biological response to bone precursor cells. Tissue Eng. Part A 2008, 14, 195-206. [CrossRef] [PubMed]

30. Canham, L.T. Bioactive silicon structure fabrication through nanoetching techniques. Adv. Mater. 1995, 7, 1033-1037. [CrossRef]

31. Gryshkov, O.; Klyui, N.I.; Temchenko, V.P.; Kyselov, V.S.; Chatterjee, A.; Belyaev, A.E.; Lauterboeck, L.; Iarmolenko, D.; Glasmacher, B. Porous biomorphic silicon carbide ceramics coated with hydroxyapatite as prospective materials for bone implants. Mater. Sci. Eng. C 2016, 68, 143-152. [CrossRef] [PubMed]

32. Angelescu, A.; Kleps, I.; Mihaela, M.; Simion, M.; Neghina, T.; Petrescu, S.; Moldovan, N.; Paduraru, C.; Raducanu, A. Porous silicon matrix for applications in biology. Rev. Adv. Mater. Sci. 2003, 5, 440-449.

33. Zhou, X.; Moussa, F.M.; Mankoci, S.; Ustriyana, P.; Zhang, N.; Abdelmagid, S.; Molenda, J.; Murphy, W.L.; Safadi, F.F.; Sahai, N. Orthosilicic acid, $\mathrm{Si}(\mathrm{OH}) 4$, stimulates osteoblast differentiation in vitro by upregulating miR-146a to antagonize NF-кB activation. Acta Biomaterialia 2016, 39, 192-202. [CrossRef] [PubMed]

34. Andrew, J.S.; Anglin, E.J.; Wu, E.C.; Chen, M.Y.; Cheng, L.; Freeman, W.R.; Sailor, M.J. Sustained release of a monoclonal antibody from electrochemically prepared mesoporous silicon oxide. Adv. Funct. Mater. 2010, 20, 4168-4174. [CrossRef] [PubMed]

35. Foraker, A.B.; Walczak, R.J.; Cohen, M.H.; Boiarski, T.A.; Grove, C.F.; Swaan, P.W. Microfabricated porous silicon particles enhance paracellular delivery of insulin across intestinal Caco-2 cell monolayers. Pharm. Res. 2003, 20, 110-116. [CrossRef] [PubMed]

36. Jarvis, K.L.; Barnes, T.J.; Prestidge, C.A. Thermal oxidation for controlling protein interactions with porous silicon. Langmuir 2010, 26, 14316-14322. [CrossRef] [PubMed]

37. Prestidge, C.A.; Barnes, T.; Mierczynska-Vasilev, A.; Skinner, W.; Peddie, F.; Barnett, C. Loading and release of a model protein from porous silicon powders. Physica Status Solidi A 2007, 204, 3361-3366. [CrossRef]

38. Zilony, N.; Rosenberg, M.; Holtzman, L.; Schori, H.; Shefi, O.; Segal, E. Prolonged controlled delivery of nerve growth factor using porous silicon nanostructures. J. Control. Release 2017, 257, 51-59. [CrossRef] [PubMed]

39. Zilony-Hanin, N.; Rosenberg, M.; Richman, M.; Yehuda, R.; Schori, H.; Motiei, M.; Rahimipour, S.; Groisman, A.; Segal, E.; Shefi, O. Neuroprotective effect of nerve growth factor loaded in porous silicon nanostructures in an Alzheimer's disease model and potential delivery to the brain. Small 2019, 2019, 1904203. [CrossRef] [PubMed]

40. Kilpeläinen, M.; Mönkäre, J.; Vlasova, M.A.; Riikonen, J.; Lehto, V.-P.; Salonen, J.; Järvinen, K.; Herzig, K.-H. Nanostructured porous silicon microparticles enable sustained peptide (Melanotan II) delivery. Eur. J. Pharm. Biopharm. 2011, 77, 20-25. [CrossRef] [PubMed]

41. Prestidge, C.A.; Barnes, T.J.; Lau, C.-H.; Barnett, C.; Loni, A.; Canham, L. Mesoporous silicon: A platform for the delivery of therapeutics. Expert Opin. Drug Deliv. 2007, 4, 101-110. [CrossRef] [PubMed]

42. Limnell, T.; Riikonen, J.; Salonen, J.; Kaukonen, A.; Laitinen, L.; Hirvonen, J.; Lehto, V.-P. Surface chemistry and pore size affect carrier properties of mesoporous silicon microparticles. Int. J. Pharm. 2007, 343, 141-147. [CrossRef] [PubMed]

43. Pastor, E.; Matveeva, E.; Valle-Gallego, A.; Goycoolea, F.M.; Garcia-Fuentes, M. Protein delivery based on uncoated and chitosan-coated mesoporous silicon microparticles. Colloids Surf. B Biointerfaces 2011, 88, 601-609. [CrossRef] [PubMed]

44. Prestidge, C.A.; Barnes, T.; Mierczynska-Vasilev, A.; Kempson, I.; Peddie, F.; Barnett, C. Peptide and protein loading into porous silicon wafers. Physica Status Solidi A 2008, 205, 311-315. [CrossRef]

45. Salonen, J.; Laitinen, L.; Kaukonen, A.; Tuura, J.; Björkqvist, M.; Heikkilä, T.; Vähä-Heikkilä, K.; Hirvonen, J.; Lehto, V.-P. Mesoporous silicon microparticles for oral drug delivery: Loading and release of five model drugs. J. Control. Release 2005, 108, 362-374. [CrossRef] [PubMed]

46. McInnes, S.J.; Turner, C.T.; Al-Bataineh, S.A.; Leccardi, M.J.A.; Irani, Y.; Williams, K.A.; Cowin, A.J.; Voelcker, N.H. Surface engineering of porous silicon to optimise therapeutic antibody loading and release. J. Mater. Chem. B 2015, 3, 4123-4133. [CrossRef]

47. Solomon, L.B.; Callary, S.A.; Boopalan, P.; Chakrabarty, A.; Costi, J.J.; Howie, D.W. Impaction bone grafting of segmental bone defects in femoral non-unions. Acta Orthop. Belg. 2013, 79, 64-70. [PubMed]

48. Ahlmann, E.; Patzakis, M.; Roidis, N.; Shepherd, L.; Holtom, P. Comparison of anterior and posterior iliac crest bone grafts in terms of harvest-site morbidity and functional outcomes. JBJS 2002, 84, 716-720. [CrossRef] [PubMed] 
49. Boone, D.W. Complications of iliac crest graft and bone grafting alternatives in foot and ankle surgery. Foot Ankle Clin. 2003, 8, 1-14. [CrossRef]

50. Velchuru, V.R.; Satish, S.G.; Petri, G.J.; Sturzaker, H.G. Hernia through an iliac crest bone graft site: Report of a case and review of the literature. Bull. NYU Hosp. Joint Dis. 2006, 63, 166.

51. Massad-Ivanir, N.; Shtenberg, G.; Tzur, A.; Krepker, M.A.; Segal, E. Engineering nanostructured porous $\mathrm{SiO}_{2}$ surfaces for bacteria detection via "direct cell capture". Anal. Chem. 2011, 83, 3282-3289. [CrossRef] [PubMed]

52. Charnay, C.; Bégu, S.; Tourné-Péteilh, C.; Nicole, L.; Lerner, D.; Devoisselle, J.-M. Inclusion of ibuprofen in mesoporous templated silica: Drug loading and release property. Eur. J. Pharm. Biopharm. 2004, 57, 533-540. [CrossRef] [PubMed]

53. Kirsch, T.; Nickel, J.; Sebald, W. Isolation of recombinant BMP receptor IA ectodomain and its 2: 1 complex with BMP-2. FEBS Lett. 2000, 468, 215-219. [CrossRef]

54. Kübler, N.; Reuther, J.; Faller, G.; Kirchner, T.; Ruppert, R.; Sebald, W. Inductive properties of recombinant human BMP-2 produced in a bacterial expression system. Int. J. Oral Maxillofac. Surg. 1998, 27, 305-309. [CrossRef]

55. Shtenberg, G.; Massad-Ivanir, N.; Fruk, L.; Segal, E. Nanostructured porous si optical biosensors: Effect of thermal oxidation on their performance and properties. ACS Appl. Mater. Interfaces 2014, 6, 16049-16055. [CrossRef] [PubMed]

56. Tzur-Balter, A.; Rubinski, A.; Segal, E. Designing porous silicon-based microparticles as carriers for controlled delivery of mitoxantrone dihydrochloride. J. Mater. Res. 2013, 28, 231-239. [CrossRef]

57. Tamm, L.K.; Tatulian, S.A. Infrared spectroscopy of proteins and peptides in lipid bilayers. Quarter. Rev. Biophys. 1997, 30, 365-429. [CrossRef] [PubMed]

58. Low, S.P.; Williams, K.A.; Canham, L.T.; Voelcker, N.H. Evaluation of mammalian cell adhesion on surface-modified porous silicon. Biomaterials 2006, 27, 4538-4546. [CrossRef] [PubMed]

59. Tzur-Balter, A.; Gilert, A.; Massad-Ivanir, N.; Segal, E. Engineering porous silicon nanostructures as tunable carriers for mitoxantrone dihydrochloride. Acta Biomaterialia 2013, 9, 6208-6217. [CrossRef] [PubMed]

60. Na, K.; won Kim, S.; Sun, B.K.; Woo, D.G.; Yang, H.N.; Chung, H.M.; Park, K.H. Osteogenic differentiation of rabbit mesenchymal stem cells in thermo-reversible hydrogel constructs containing hydroxyapatite and bone morphogenic protein-2 (BMP-2). Biomaterials 2007, 28, 2631-2637. [CrossRef] [PubMed]

61. Porta, G.D.; Nguyen, B.N.B.; Campardelli, R.; Reverchon, E.; Fisher, J.P. Synergistic effect of sustained release of growth factors and dynamic culture on osteoblastic differentiation of mesenchymal stem cells. J. Biomed. Mater. Res. Part. A 2015, 103, 2161-2171. [CrossRef] [PubMed]

62. Kumeria, T.; McInnes, S.J.P.; Maher, S.; Santos, A. Porous silicon for drug delivery applications and theranostics: Recent advances, critical review and perspectives. Expert Opin. Drug Deliv. 2017, 14, 1407-1422. [CrossRef] [PubMed]

63. Tieu, T.; Alba, M.; Elnathan, R.; Cifuentes-Rius, A.; Voelcker, N.H. Advances in porous silicon-based nanomaterials for diagnostic and therapeutic applications. Adv. Ther. 2019, 2, 1800095. [CrossRef]

64. Tzur-Balter, A.; Shtenberg, G.; Segal, E. Porous silicon for cancer therapy: From fundamental research to the clinic. Rev. Chem. Eng. 2015, 31, 193-207. [CrossRef]

65. Jarvis, K.L.; Barnes, T.J.; Prestidge, C.A. Surface chemistry of porous silicon and implications for drug encapsulation and delivery applications. Adv. Colloid Interface Sci. 2012, 175, 25-38. [CrossRef] [PubMed]

66. Nieto, A.; Hou, H.; Moon, S.W.; Sailor, M.J.; Freeman, W.R.; Cheng, L. Surface engineering of porous silicon microparticles for intravitreal sustained delivery of rapamycin. Investig. Ophthalmol. Vis. Sci. 2015, 56, 1070-1080. [CrossRef] [PubMed]

67. Canham, L. Handbook of Porous Silicon; Springer: New York, NY, USA, 2014.

68. Jonkheijm, P.; Weinrich, D.; Schröder, H.; Niemeyer, C.M.; Waldmann, H. Chemical strategies for generating protein biochips. Angewandte Chemie Int. Ed. 2008, 47, 9618-9647. [CrossRef] [PubMed]

69. Kim, J.; Cho, J.; Seidler, P.M.; Kurland, N.E.; Yadavalli, V.K. Investigations of chemical modifications of amino-terminated organic films on silicon substrates and controlled protein immobilization. Langmuir 2010, 26, 2599-2608. [CrossRef] [PubMed]

70. Di Marco, M.; Shamsuddin, S.; Razak, K.A.; Aziz, A.A.; Devaux, C.; Borghi, E.; Levy, L.; Sadun, C. Overview of the main methods used to combine proteins with nanosystems: Absorption, bioconjugation, and encapsulation. Int. J. Nanomed. 2010, 5, 37. [CrossRef] 
71. Rickard, D.J.; Sullivan, T.A.; Shenker, B.J.; Leboy, P.S.; Kazhdan, I. Induction of rapid osteoblast differentiation in rat bone marrow stromal cell cultures by dexamethasone and BMP-2. Dev. Biol. 1994, 161, 218-228. [CrossRef] [PubMed]

72. Varkey, M.; Kucharski, C.; Haque, T.; Sebald, W.; Uludag, H. In vitro osteogenic response of rat bone marrow cells to bFGF and BMP-2 treatments. Clin. Orthop. Relat. Res. 2006, 443, 113-123. [CrossRef] [PubMed]

73. Yamaguchi, A.; Katagiri, T.; Ikeda, T.; Wozney, J.M.; Rosen, V.; Wang, E.A.; Kahn, A.J.; Suda, T.; Yoshiki, S. Recombinant human bone morphogenetic protein-2 stimulates osteoblastic maturation and inhibits myogenic differentiation in vitro. J. Cell Biol. 1991, 113, 681-687. [CrossRef] [PubMed]

74. Chen, S.; Shi, X.; Morita, H.; Li, J.; Ogawa, N.; Ikoma, T.; Hayakawa, S.; Shirosaki, Y.; Osaka, A.; Hanagata, N. BMP-2-loaded silica nanotube fibrous meshes for bone generation. Sci. Technol. Adv. Mater. 2011, 12, 065003. [CrossRef] [PubMed]

75. Moore, L.; Gatica, M.; Kim, H.; Osawa, E.; Ho, D. Multi-Protein delivery by nanodiamonds promotes bone formation. J. Dental Res. 2013, 92, 976-981. [CrossRef] [PubMed]

76. Zhou, P.; Cheng, X.; Xia, Y.; Wang, P.; Zou, K.; Xu, S.; Du, J. Organic/Inorganic composite membranes based on poly(l-lactic-co-glycolic acid) and mesoporous silica for effective bone tissue engineering. ACS Appl. Mater. Interfaces 2014, 6, 20895-20903. [CrossRef] [PubMed]

77. Crouzier, T.; Ren, K.; Nicolas, C.; Roy, C.; Picart, C. Layer-By-Layer films as a biomimetic reservoir for rhBMP-2 delivery: Controlled differentiation of myoblasts to osteoblasts. Small 2009, 5, 598-608. [CrossRef] [PubMed]

78. Hermanson, G.T. (Ed.) Introduction to bioconjugation. In Bioconjugate Techniques, 3rd ed.; Academic Press: Boston, MA, USA, 2013; 125p.

79. Hu, L.; Yin, C.; Zhao, F.; Ali, A.; Ma, J.; Qian, A. Mesenchymal stem cells: Cell fate decision to osteoblast or adipocyte and application in osteoporosis treatment. Int. J. Mol. Sci. 2018, 19, 360. [CrossRef] [PubMed]

80. Jiang, Y.; Jahagirdar, B.N.; Reinhardt, R.L.; Schwartz, R.E.; Keene, C.D.; Ortiz-Gonzalez, X.R.; Reyes, M.; Lenvik, T.; Lund, T.; Blackstad, M. Pluripotency of mesenchymal stem cells derived from adult marrow. Nature 2002, 418, 41. [CrossRef] [PubMed]

81. Tocci, A.; Forte, L. Mesenchymal stem cell: Use and perspectives. Hematol. J. 2003, 4, 92-96. [CrossRef] [PubMed]

82. Hajj-Hassan, M.; Khayyat-Kholghi, M.; Wang, H.; Chodavarapu, V.; Henderson, J.E. Response of murine bone marrow-derived mesenchymal stromal cells to dry-etched porous silicon scaffolds. J. Biomed. Mater. Res. Part. A 2011, 99, 269-274. [CrossRef] [PubMed]

83. Wang, P.Y.; Clements, L.R.; Thissen, H.; Jane, A.; Tsai, W.B.; Voelcker, N.H. Screening mesenchymal stem cell attachment and differentiation on porous silicon gradients. Adv. Funct. Mater. 2012, 22, 3414-3423. [CrossRef]

84. Chen, D.; Zhao, M.; Mundy, G.R. Bone morphogenetic proteins. Growth Factors 2004, 22, 233-241. [CrossRef] [PubMed]

85. Kempen, D.H.; Lu, L.; Hefferan, T.E.; Creemers, L.B.; Maran, A.; Classic, K.L.; Dhert, W.J.; Yaszemski, M.J. Retention of in vitro and in vivo BMP-2 bioactivities in sustained delivery vehicles for bone tissue engineering. Biomaterials 2008, 29, 3245-3252. [CrossRef] [PubMed]

86. Aubin, J.E. Regulation of osteoblast formation and function. Rev. Endocr. Metabol. Disord. 2001, 2, 81-94. [CrossRef] [PubMed]

87. Young, S.; Bashoura, A.G.; Borden, T.; Baggett, L.S.; Jansen, J.A.; Wong, M.; Mikos, A.G. Development and characterization of a rabbit alveolar bone nonhealing defect model. J. Biomed. Mater. Res. Part. A 2008, 86, 182-194. [CrossRef] [PubMed]

88. Mikos, A.G.; Sarakinos, G.; Lyman, M.D.; Ingber, D.E.; Vacanti, J.P.; Langer, R. Prevascularization of porous biodegradable polymers. Biotechnol. Bioeng. 1993, 42, 716-723. [CrossRef] [PubMed]

89. Vacanti, J.P.; Morse, M.A.; Saltzman, W.M.; Domb, A.J.; Perez-Atayde, A.; Langer, R. Selective cell transplantation using bioabsorbable artificial polymers as matrices. J. Pediatr. Sur. 1988, 23, 3-9. [CrossRef]

90. Amini, A.R.; Adams, D.J.; Laurencin, C.T.; Nukavarapu, S.P. Optimally porous and biomechanically compatible scaffolds for large-area bone regeneration. Tissue Eng. Part. A 2012, 18, 1376-1388. [CrossRef] [PubMed] 
91. Lee, D.J.; Kwon, J.; Kim, Y.I.; Wang, X.; Wu, T.J.; Lee, Y.T.; Kim, S.; Miguez, P.; Ko, C.C. Effect of pore size in bone regeneration using polydopamine-laced hydroxyapatite collagen calcium silicate scaffolds fabricated by 3D mould printing technology. Orthod. Craniofac. Res. 2019, 22, 127-133. [CrossRef] [PubMed]

92. Lam, C.X.F.; Hutmacher, D.W.; Schantz, J.-T.; Woodruff, M.A.; Teoh, S.H. Evaluation of polycaprolactone scaffold degradation for 6 months in vitro and in vivo. J. Biomed. Mater. Res. Part. A 2009, 90, 906-919. [CrossRef] [PubMed]

93. Shor, L.; Güçeri, S.; Wen, X.; Gandhi, M.; Sun, W. Fabrication of three-dimensional polycaprolactone/hydroxyapatite tissue scaffolds and osteoblast-scaffold interactions in vitro. Biomaterials 2007, 28, 5291-5297. [CrossRef] [PubMed]

94. Sukanya, V.S.; Mohan, P.V. Degradation of poly( $\varepsilon$-caprolactone) and bio-interactions with mouse bone marrow mesenchymal stem cells. Colloids Surf. B Biointerfaces 2018, 163, 107-118. [CrossRef]

95. Williams, J.M.; Adewunmi, A.; Schek, R.M.; Flanagan, C.L.; Krebsbach, P.H.; Feinberg, S.E.; Hollister, S.J.; Das, S. Bone tissue engineering using polycaprolactone scaffolds fabricated via selective laser sintering. Biomaterials 2005, 26, 4817-4827. [CrossRef] [PubMed]

(C) 2019 by the authors. Licensee MDPI, Basel, Switzerland. This article is an open access article distributed under the terms and conditions of the Creative Commons Attribution (CC BY) license (http://creativecommons.org/licenses/by/4.0/). 